Dhaka Univ. J. Biol. Sci. 21(1): 39-46, 2012 (January)

\title{
THE AGRICULTURAL POTENTIALITY OF SOME WETLAND SOILS UNDER SYLHET BASIN OF BANGLADESH
}

\author{
M. J. Uddin*, A. S. M. Mohiuddin, A. T. M. M. Kamal and M. Anwar Hossain ${ }^{1}$ \\ Department of Soil, Water and Environment, University of Dhaka, Dhaka-1000, Bangladesh
}

Key words: Wetland soils, Sylhet basin, Agricultural potentiality

\begin{abstract}
An investigation was conducted to study some representative wetland soils under Sylhet basin of Bangladesh with a view to evaluating the agricultural potentiality and its management options. The soils are nutritionally very productive. Soil textural and other environmental conditions are more appropriate for rice production. The contents of nitrogen and boron is low. Probably, the denitrification process leads to the loss of nitrogen in this basin soils. Other nutrients seem to be at a balanced condition for the successful growth of deep water rice. Boro and deep water T. Aman were introduced in the study area in recent times. Availability of irrigation water in the dry periods and shallow inundation level in the monsoon may be the main cause of such cropping pattern. Due to the changes in landuse, demand for nitrogen and phophorus fertilizer have increased. $\mathrm{pH}$ value stands near neutral which indicates the agricultural viability of the soils. The present investigations ascertained that the study area including the wetland of Bangladesh can be economically exploited through appropriate nutrient management without any extra agro-chemical use.
\end{abstract}

\section{Introduction}

Wetland soils' development and properties are strongly influenced by topography or permanent saturation in the upper part of the land"(1). More than two-thirds of Bangladesh may be classified as wetland according to the definition enunciated in the RAMSAR Convention which constitute about $70 \%$ of the territory of Bangladesh ${ }^{(2)}$. It is thus obvious that study of wetland soil in Bangladesh occupies an important position so far as its characteristics and management are concerned because $95 \%$ of the total rice area of Bangladesh is on wetland soils(3).

The study area lies between 23039' and 24016 $\mathrm{N}$ latitudes and between 90 ${ }^{\circ} 44^{\prime}$ and $91^{\circ}$ 51' E longitudes under the Surma-Kusiyara floodplains on Bangladesh. Generally the basins of Bangladesh are moderate to deeply flooded with fine to medium textural class which has developed on unconsolidated alluvial sediments. Deep water rice is the most

*Corresponding author: <mjuddin66@yahoo.com>.

1Pathikrit Education Development Society (PEDS), House \# 33, Road \# 4, Dhanmondi, Dhaka-1205, Bangladesh. 
extensive crop in this site. In fact, low land soils are agriculturally productive and contains high quantity of soil nutrients. To explore the agricultural potentiality of these soils, a more intensive and detailed study is important for basin resource inventorization.

The present study aims at evaluating the agricultural potentialities of the area with particular emphasis on the soil fertility status and suggesting possible soil management options for sustaining soil productivity.

\section{Materials and Methods}

The study area is located in the wetland basin area of Brahmanbaria district of Bangladesh under the Sylhet basin of Surma-Kusiyara alluvium. The four soil series studied to evaluate its agricultural potentialities were Balanganj, Phagu, Nasirnagar and Nabinagar. GPS have been used to locate the geographical position of the soil samples.

Balaganj series is located at $24^{\circ} 06^{\prime} 494^{\prime \prime} \mathrm{N}$ to $91^{\circ} 07^{\prime} 622^{\prime \prime} \mathrm{E}$ in the medium highland phase. It is seasonally shallowly flooded, poorly drained soils developed in mixed textured alluvium occupying in the gently sloping ridges. These are mixed grey and dark brown, friable, silt loam to loam subsoil with strong to moderate subangular blocky structure and patchy to continuous grey cutans on ped faces. Phagu series located at $24^{\circ} 05^{\prime} 572^{\prime \prime} \mathrm{N}$ to $91^{\circ} 08^{\prime} 384^{\prime \prime} \mathrm{E}$ in the slope of basin and is poorly drained, seasonally deeply flooded soils developed in the basins and basin margins of Surma-Kusiyara floodplain. These have a grey to dark grey, clay sub-soil usually with strong prismatic and angular blocky structure and continuous grey or dark grey cutans along the ped faces. Nasirnagar series is located at $24^{\circ} 05^{\prime \prime} 914^{\prime \prime}$ to $91^{\circ} 06^{\prime} 643^{\prime \prime} \mathrm{E}$ in the nearly level basin sites. It comprises seasonally very deeply flooded, very poorly drained, moderately fine textured soils developed in the Titas valley of the Sylhet basin. These have a dark grey to very dark grey, mottled brown, silty clay loam sub soil. Nabinagar series is located at $24^{\circ} 07^{\prime} 966^{\prime \prime} \mathrm{N}$ to $91^{\circ} 08^{\prime} 161^{\prime \prime} \mathrm{E}$ in the basin depressions. It comprises seasonally very deeply flooded, very poorly drained soils developed in fine textured alluvium on the Titas valley of the Sylhet basins. They have a very dark grey, silty clay to clay and A horizon with common brown mottles overlying a silt loam to silty clay loam oxidized substratum.

The area under study forms a part of the 'Bengal basin' filled with quaternary sediments ${ }^{(4)}$. The materials of the surface area are of recent to sub-recent age and estimated to be of around 200 years according to an estimate ${ }^{(5)}$. The lithology of the recent and sub recent alluvia dominated by silt and clay size particles(6). Soil samples were collected, air dried, grinded and screened through sieve. The samples were analyzed for $\mathrm{pH}$, organic matter, $\mathrm{N}, \mathrm{P}, \mathrm{K}, \mathrm{Ca}, \mathrm{Mg}, \mathrm{S}, \mathrm{B}, \mathrm{Cu}, \mathrm{Zn}, \mathrm{Fe}$ and $\mathrm{Mn}$. $\mathrm{pH}$ of soils was determined at a soil-water ratio $1.0: 2.5$ using a $\mathrm{pH}$ meter and the organic carbon content of soils was determined volumetrically by wet oxidation method as described by Jackson $^{(7)}$. The total nitrogen in soils was determined by Kjeldahl's method as described by Jackson(7). Available phosphorous was determined by Olsen method(7). Ammonium 
acetate extract was prepared and the exchangeable $\mathrm{Ca}, \mathrm{Mg}, \mathrm{K}$ were determined from the extracts( ${ }^{(8)}$. Available sulphur was determined by a spectrophoto-meter after developing turbidity with barium chloride ${ }^{(7)}$. Boron was determined by Azomethine- $\mathrm{H}$ reagent buffer solution, $\mathrm{Zn}, \mathrm{Cu}$, Fe and $\mathrm{Mn}$ were extracted with DTPA solution(9). Soil physical attributes were assessed in the field using standard field methodology $y^{(10)}$.

Sylhet basin is a vast depressed area lying between the Surma-Kushiyara floodplain and the Old Brahmaputra floodplain. The relief comprises of high river levees surrounding extensive basins, the centres of which stay wet through the dry season. The whole area are subject to flash floods and most of the land are deeply or very deeply flooded in the monsoon season. The difference in the elevation between river banks and haor centres varies from five meters or more. Clays predominate in the basins, with peat in some basin centres(6). Surma-Kushiyara floodplain is formed by the sediments brought in by the rivers draining into the Meghna catchment area from the Northern and Eastern hills. It comprises alternate narrow long ridges and deep narrow inter-ridge depressions with some broad basins. The relief is generally smooth, comprising broad ridges and basins, but it is locally irregular along river channels.

The study area has a pronounced tropical monsoon climate. Total annual rainfall is 2420 to $2430 \mathrm{~mm}$. Excess of rainfall over evaporation during rainy season have been recorded in an estimate. There is plenty of rainfall during monsoon and most of this rainfall occurs during the months of May, June and July. The highest and lowest mean temperatures are 33.5 and $12.3^{\circ} \mathrm{C}$, respectively in the months of May to January. The summer begins at the end of March and merged with the rainy season which continues up to September.

The main rivers in the study sites are the Meghna, The Dhaleswar, the Titas, the Bansi, the Baliaguri, the Pagla, the Saldah and the Buri. The Meghna river flows along the margin area. The Meghna is navigable throughtout the year. All other rivers are navigable during the rainy season only. The Titas taking off from the Meghna several kilometers north of Bhairab bazaar has meandered through the study area and finally has joined the Meghna again near Nabinagar Upazila several kilometers downstream of Bhairab bazaar. Several creeks during draining Tripura hills join the Titas river. Normally, the floodlevel of the Meghna river starts rising from May due to increased discharge of its tributaries and discharges are usually at their highest level from July to September; from November it starts receeding and finally touches lowest discharges in January-March. Creeks draining the Tripura hills swell rapidly and flows for a few days at a time after heavy pre-monsoon rainfall in its catchment areas i. e., Tripura hills.

The Sylhet basin is subdivided into the Surma-Kusiayara floodplain and Titas floodplain because of its lower elevation receives run-off from the Tripura hills, neighbouring piedmont apron and adjoining Old Meghna estuarine floodplain as well as spillings from the Meghna river. In the rainy season, it becomes an enormous lake more 
than 12 feet deep. Deep flooding, sudden rise of flood level and current water prevent the cultivation of kharif crops in most of the area. However, boro rice is extensively grown because large areas remain wet for most or all of dry season(6).

\section{Results and Discussion}

The textural class was silt loam in the Balanganj, Phagu and Nasirnagar soil series where as Nabinagar soil series was silty clay (Table 1). The best soils for agricultural crops specifically for the rice crops are the silty clay to clay loam ${ }^{(11)}$ which showed relevancy with the above textural class. Soil texture always influences the drainage conditions of the soils as well as crop performance. The drainage conditions of these soils varied from poor to very poor. Seasonal submergence followed by drying the condition of oxidation and reduction phenomena in the studied soils. The soil reaction closely followed the course of oxidation and reduction conditions because the soils initially contained considerable amounts of $\mathrm{Fe}$ and $\mathrm{Mn}$ bearing minerals ${ }^{(6)}$ which are subject to oxidation and reduction reactions. The grey colour of these soils is probably due to the above reasons. The development of coating along the ped faces, fissures and pores in the subsoil are typical characteristics of theses soils. These coatings are not clay skins but are flood coatings which appears to have developed from the materials that are taken down from the surface under flooded conditions. Thus, continuous thick dark grey to continuous dark grey cutans along ped faces are found in Balaganj and Phagu soils. All the soils under present study developed flood coatings and variously coloured mottles along the old root channels and pores and prevails the vital characteristics of hydromorphic nature.

Table 1. Some physical and environmental attributes of the soils.

\begin{tabular}{|c|c|c|c|c|c|c|}
\hline $\begin{array}{l}\text { Soil } \\
\text { series }\end{array}$ & $\begin{array}{l}\text { USDA } \\
\text { family }\end{array}$ & Topography & Drainage & Texture & $\begin{array}{l}\text { Land } \\
\text { type }\end{array}$ & $\begin{array}{l}\text { Area } \\
\text { (ha) }\end{array}$ \\
\hline Balaganj & $\begin{array}{l}\text { Loamy, mixed, nonacid, } \\
\text { typic endoaquepts }\end{array}$ & $\begin{array}{l}\text { Gently } \\
\text { sloping ridge }\end{array}$ & Poor & $\begin{array}{l}\text { Silt } \\
\text { loam }\end{array}$ & $\begin{array}{l}\text { Low } \\
\text { land }\end{array}$ & 23,301 \\
\hline Phagu & $\begin{array}{l}\text { Loamy, mixed, nonacid, } \\
\text { typic endoaquepts }\end{array}$ & $\begin{array}{l}\text { Slope of } \\
\text { basin }\end{array}$ & $"$ & $"$ & $"$ & $3,08,980$ \\
\hline Nasirnagar & $\begin{array}{l}\text { Loamy, mixed, nonacid, } \\
\text { typic endoaquepts }\end{array}$ & $\begin{array}{l}\text { Nearly level } \\
\text { basin }\end{array}$ & $\begin{array}{l}\text { Very } \\
\text { poor }\end{array}$ & $"$ & $\begin{array}{l}\text { Very low } \\
\text { land }\end{array}$ & 5,748 \\
\hline Nabinagar & $\begin{array}{l}\text { Clayey, mixed, nonacid, } \\
\text { typic endoaquepts }\end{array}$ & $\begin{array}{l}\text { Basin } \\
\text { depression }\end{array}$ & $"$ & $\begin{array}{l}\text { Silty } \\
\text { clay }\end{array}$ & $"$ & 5,601 \\
\hline
\end{tabular}

The organic matter content of the soils varied from 0.96 to 1.17 with a mean of 1.10 per cent. The $\mathrm{pH}$ value of the studied wetland soils ranged from 6.7 to 7.0 with a mean of 6.9 (Table 2). The decomposition and mineralization of organic matter are interrelated with successive changes in chemical reduction of the soils resulting in the lowering of redox potential and changes of $\mathrm{pH}$ to near neutrality ${ }^{(12)}$. Total nitrogen contents in the 
studied soils ranged from 0.07 to 0.09 per cent. The low nitrogen content of the soils may be attributed to the loss through denitrification. The denitrification was probably due to the poor drainage condition of the soils. The $\mathrm{C} / \mathrm{N}$ ratio of the studied soils ranged from 7 to 9 indicating agricultural suitability of these soils. Potassium contents of the soils ranged from 0.31 to $0.85 \mathrm{cmol} \mathrm{p}^{+} / \mathrm{kg}$ with an average of $0.48 \mathrm{cmol} \mathrm{p}^{+} / \mathrm{kg}$. Sodium contents of the soils ranged from 1.00 to $1.13 \mathrm{cmol} \mathrm{p}^{+} / \mathrm{kg}$ with an average of $1.04 \mathrm{cmol} \mathrm{p}^{+} / \mathrm{kg}$ (Table

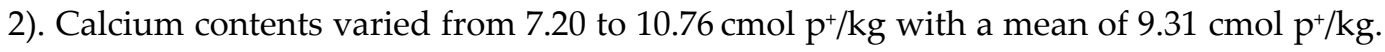

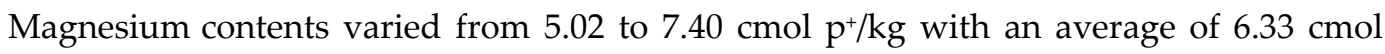
$\mathrm{p}^{+} / \mathrm{kg}$ and can be considered as high. The $\mathrm{Ca} / \mathrm{Mg}$ ratio of the studied soils varied from 1.30 to 1.80 and the mean ratio was 1.50 (Table 2). Hence, the level of basic cations is not satisfactory as because of the non-calcareous nature of the parent materials of this area. $\mathrm{The} \mathrm{Mg} / \mathrm{K}$ ratio varied from 8.67 to 20.23 with the average being 13.25.

Available P contents varied from 7.0 to $23.0 \mu \mathrm{gm} / \mathrm{gm}$ with an average of $16.25 \mu \mathrm{g} / \mathrm{g}$ (Table 2). Here, low category of $\mathrm{P}$ may be due to the intensive cropping of the basin area. Slow release fertilizer can be used during land preparation or incorporated with soils prior to the transplanting of rice. Sulphur contents varied from 23.0 to $49.0 \mu \mathrm{g} / \mathrm{g}$ soil with an average of $33.75 \mu \mathrm{g} / \mathrm{g}$. Removal or burning of the rice straw in combination with the use of sulphur free fertilizers has resulted in depletion of sulphur. It can be remedied by the supply of sulphur containing fertilizers like ammonium sulfate or gypsum. Boron contents varied from 0.06 to $0.14 \mu \mathrm{g} / \mathrm{g}$ and an average of $0.11 \mu \mathrm{g} / \mathrm{g}$. Zinc contents varied from 2.7 to $6.5 \mathrm{micro-gm} / \mathrm{ml}$. Zinc deficiency was generally observed in soils with rice cultivated areas of Bangladesh(2). Copper contents varied from 8.6 to $19.9 \mu \mathrm{g} / \mathrm{g}$ and an average of $14.57 \mu \mathrm{g} / \mathrm{g}$. Iron content varied from 324.0 to $523.0 \mu \mathrm{g} / \mathrm{g}$. Manganese content varied from 46.7 to $105.1 \mu \mathrm{g} / \mathrm{g}$ and average was $76.52 \mu \mathrm{g} / \mathrm{g}$ (Table 2). The reaction of the soil enhanced the availability of $\mathrm{P}$ and Mo while suppressed the toxicity of $\mathrm{Mn}, \mathrm{Al}$ and Fe. Here antagonistic effect of $\mathrm{Mn}$ and possibly of $\mathrm{Mg}$ on $\mathrm{Zn}$ uptake by rice plants is expected ${ }^{(13)}$.

To assess the agricultural potentiality of the studied soils, the soils were classified into three categories as low, medium and optimum using the fertilizer recommendation guide (14). From that recommendation, the studied soils were verified (Table 3) and categorized according to its potentialities from which an advisory service can be provided to the farmers to use the present level of fertilizer recommendations which may help to reduce the extra cost of fertilizers. In the present investigation, the soils were highly productive nutritionally. The content of nitrogen and boron is low to very low. The application of boron and nitrogen should be on the basis of yield goal level. Most probably, the denitrification process leads to the loss of nitrogen in this basin soils, the other nutrients maintain a balance level for the successful growth of rice. Comparing the past and present land use data, boro and deep water T. Aman were introduced in the study area (Table 4). Introduction of irrigation facility in the dry season and shallow 


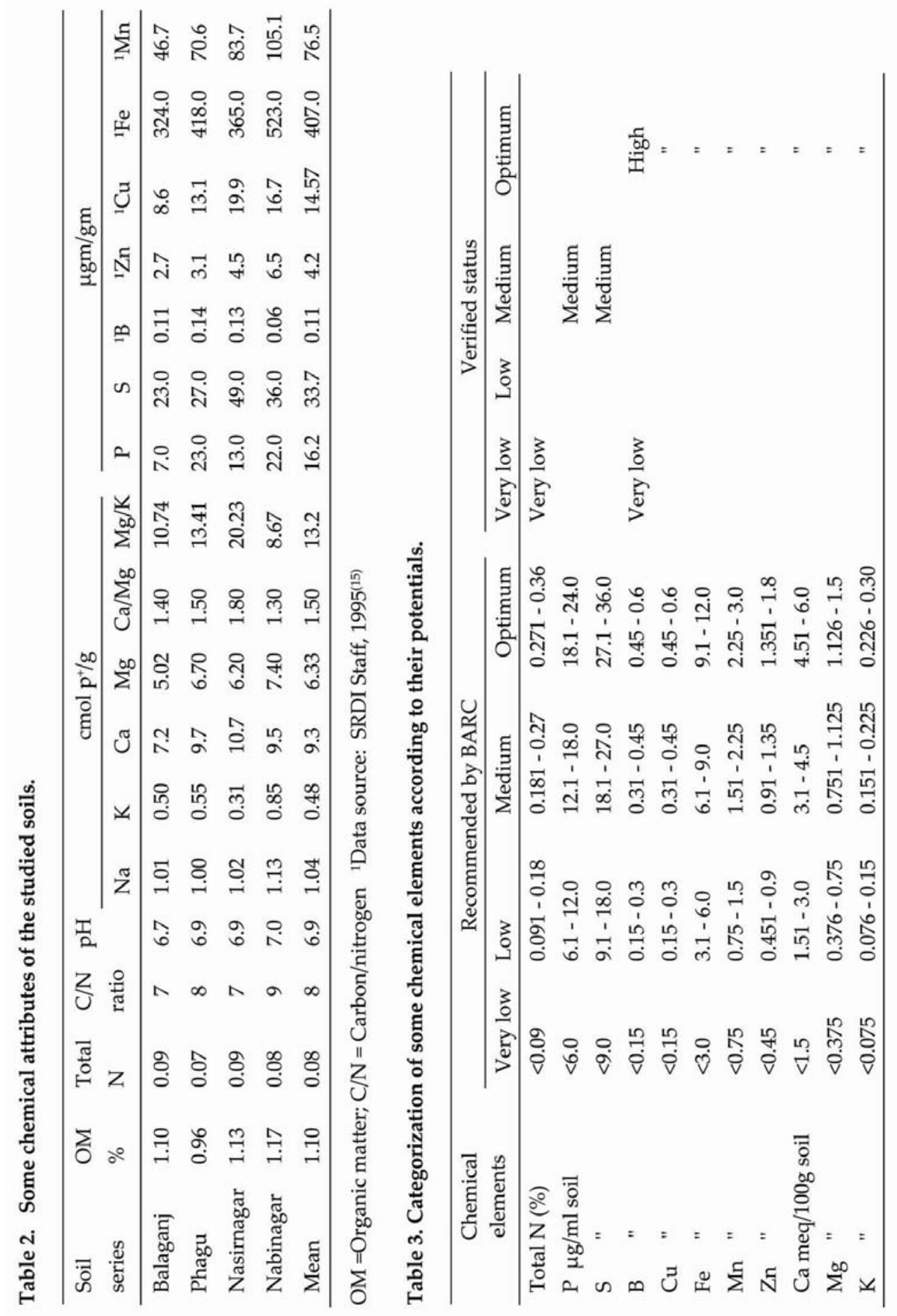


inundation level in the monsoon may be the main cause of such cropping pattern. Agricultural viability of soils depend on the organic carbon content of soils. Organic carbon is the skeletal of the soil mass and acts as a regulator of soil bio-chemical and physico-chemical behaviour. On the other hand, soil $\mathrm{pH}$ plays a very vital role in grouping the soils into different classes and has a profound influence on many factors connected with the suitability of a soil for agricultural use. In this connection, it can be advised that the studied soils will remain productive in respect of their agricultural use.

Table 4. Changing scenarios of the cropping pattern in the studied areas.

\begin{tabular}{lll}
\hline $\begin{array}{l}\text { Name of agro- } \\
\text { ecological zones }\end{array}$ & $\begin{array}{l}\text { Past land use } \\
(1965-85)\end{array}$ & $\begin{array}{l}\text { Present } \\
\text { land use }\end{array}$ \\
\hline \multirow{3}{*}{$\begin{array}{l}\text { Surma-Kusiyara } \\
\text { floodplain under } \\
\text { Sylhet basin }\end{array}$} & Rabi crop - mixed broadcast aus and aman & $\begin{array}{l}\text { Aus - T. aman } \\
\text { Boro - deep water T. aman }\end{array}$ \\
\cline { 2 - 3 } & Fallow - broadcast aman & Boro - fallow-fallow \\
& Boro(L) - fallow-fallow & Fallow - broadcast aman \\
\cline { 2 - 3 } & Grassland & Boro (L) - fallow-fallow \\
\hline
\end{tabular}

${ }^{*}$ Data source ${ }^{(18)}$.

Fertility level of this area is moderate to optimum and is believed to be enriched by siltation during flooding. Annual siltation is a characteristic feature of these soils where from the traditional natural fertility of these soils is derived ${ }^{(16)}$. The land use depends on the timing and duration of flooding. With the introduction of irrigation along with HYV of rice, the cropping pattern has been changed and HYV boro rice got preference over broadcast aman and aus as a major rice crop in the area ${ }^{(17)}$. Due to the changes in cropping pattern, demand for nitrogen and phophorus fertilizers have increased. The $\mathrm{pH}$ value stands near neutral which indicates the agricultural viability of the studied soils. The present investigation ascertained that the study area including the wetlands can be economically exploited through appropriate nutrient management and selecting the proper cropping patterns.

\section{References}

1. Moorman FR 1953. Acid sulphate soils of the tropics. Soil Sci. 95: 271-275.

2. Saheed SM 1984. Soils of Bangladesh. pp. 107-129. Proc. Int. Symp. Soil Test Crop Response Correlation Studies. BARC and SSSB, Dhaka, Bangladesh.

3. Huq SMI and GM Kamal 1993. Characteristics and dynamics of wetland soils. Freshwater Wetlands in Bangladesh: Issues and Approaches for Management. IUCN Bangladesh Country Office, Dhaka, Bangladesh.

4. Morgan JP and WG McIntire 1959. Quaternary Geology of the Bengal Basin. East Pakistan and India. Bull. Geol. Soc. Amer. 70: 319-342. 
5. Brammer H 1968. Decalcification of soils developed on calcareous Gangetic alluvium in East Pakistan. Pakistan J. Soil Sci. 2: 8-20.

6. Brammer H 1971. Bangladesh: Soil resources. AGL : SF/PAK 6, Technical Report 3, FAO, Rome.

7. Jackson ML 1962. Soil Chemical Analysis. Prentice Hall Inc. Englewood Cliffs, New Jersey, USA.

8. Black CA 1965. Methods of Soil Analysis. Amec. Soc. Agr. Inc. Pub. Madison, Wisconsin, USA.

9. Hunter AH 1984. Fertility Analytical Services in Bangladesh. A consultancy report. Contact Aid/388-0051. IADS-BARC, Dhaka.

10. FAO 1977. Guidelines for Soil Profile Description. Soil Resources Development and Conservation Services. FAO of the UN, Rome.

11. ICLARM 1988. Integrating Aquaculture with Rice Farming in Bangladesh. Feasibility and Economic Viability of its Adoption and Impacts. ICLARM contribution No. 146, Philippines.

12. IUCN 1993. Characteristics and dynamics of wetland soils in Bangladesh. IUCN. Wetland Publication, Dhaka, Bangladesh.

13. Sakai H 1979. Reports of research activities 1977-79. IRRI Agronomist, BRRI Joydevpur, Bangladesh. p. 23.

14. BARC 2005. Fertilizer Recommendation Guide. Bangladesh Agricultural Research Council. Soils Publication No. 45, Dhaka, Bangladesh.

15. SRDI Staff 1995. Land and Soil Resource Utilization Guides of Sarail Thana of Brahmanbaria district. GoB, Soil Resource Development Institute. Bangladesh.

16. Zaman SMH 1974. Deep-water rice in Bangladesh. BRRI publication No. 15. pp. 22-44. Bangladesh Rice Research Institute. Joydebpur, Bangladesh.

17. Zaman SMH 1993. Agricultural Development and Sustainability of Wetlands in Bangladesh. In: Fresh Water wetlands in Bangladesh Issues and Approaches for Management. Nishat Ainun, Zakir Hossain, Roy MK and Karim Ansarul (eds.), pp. 163-978. IUCN, Switzerland.

18. Karim Z and A Iqbal 2001. Impact of Land Degradation in Bangladesh, Changing Scenario in Agricultural Land Use. Soils Publication No. 42 . Bangladesh Agricultural Research Council, Bangladesh. 